\title{
Occurrence of Permian palynofossils from the Saltoro Formation, Shyok-Suture-Zone, Ladakh Himalaya, India
}

\author{
Ram-Awatar \\ Birbal Sahni Institute of Palaeobotany,53 University Road, Lucknow-226 007 (UP), INDIA \\ E-mail: rawatar_2003@yahoo.com
}

In India, the Shyok Suture Zone (SSZ) is tectonically intercalated between the rocks of the Indus Tsangpo Suture Zone (ITSZ) to the south and Karakoram Zone to north (Srimal 1986, Sinha 1992, Thakur 1992, Sinha and Upadhyay 1995).The major thrusts which make both boundaries are known as Shyok thrust and Karakoram thrust respectively. The Shyok Suture Zone is a complex association of Late Palaeozoic to Miocene rocks including turbidites and ophiolitic mélanges with volcanic, calcalkaline magmatic rocks, granite batholith and molasses-type sequence forming an accretionary complex. The following opinions exist regarding the tectonics of the Shyok Suture Zone: 1) It is a subduction zone older than the ITSZ (Frank et al. 1977). 2) It is a subduction zone younger than the ITSZ (Brookfield and Reynold 1981). 3) It is a tectonic repetition of the ITSZ (Rai 1982). 4) It is a back-arc complex related to the ITSZ (Thakur and Misra,1984) .5) It is a the tectonic repetition of a marginal oceanic crust that existed between the ITSZ and the Asian land mass in the Middle Cretaceous (Srimal 1986, Upadhyay et al. 1999). 6) It is a back-arc basin (Thakur and Misra 1984, Sharma 1991).

The sedimentary, volcanic and plutonic rocks of the SSZ are highly deformed and occur as tectonics slices between Ladakh and Karakoram Batholith. The lowermost unit of the Saltoro Formation is well exposed to the south of Khalsar, where it consists of thinly and even bedded, highly fissile and cleaved slates, phyllites and siltstones. A diverse palynfloral assemblage has been recovered from the siltstone unit collected from the Khalsar-Sakti road section of the same formation. The palynoflora is represented by 14 genera and 20 species of the spores and pollen grains. The significant palynotaxa of the assemblage are: Leiotriletes, Verrucosisporites, Platysaccus, Primuspollenites, Alisporites, Gondisporites, Faunipollenites, Striatopodocarpites, Densipollenites, Caheniasaccites, Scheuringipollenites, Hemiapollenites, Parasaccites,, Crescentipollenites, Corisaccites, Vesicaspora and Tetraporina. Based on the qualitative and quantitative analysis, Early to Late Permian age has been assigned to the assemblage.

Although, on the basis of the gastropods, echinoids, foraminifera and bryozoans, age of the Saltoro Formation has been assigned from Late Jurassic / Early to Middle Cretaceous (Upadhyay 2002). However, the palynomorphs recovered from the Saltoro formation are of Permian times. These palynomorphs could be found under two conditions: 1) Either the sediments (siltstone unit) containing palynofossils of Permian time remain intact in this highly tectonized region, or 2) These palynomorphs have been eroded, recycling and deposited into the tectonically active Cretaceous-trench-subduction complex that existed between the Indian and the Asian plates.

References

Brookfield ME and PH Reynold. 1981. Late Cretaceous emplacement of the Indus Suture Zone ophiolitic melanges and an Eocene -Oligocene magmatic arc on the northern edge of the Indian plate. Earth Planetary Science Letters 55:157-162

Frank W, A Gansser and V Trommsdorff. 1977. Geological observations in the Ladakh area (Himalaya): a preliminary report. Schweiz. Miner. Petrogr Mitt 57: 89-113

Rai H. 1982. Geological evidence against the Shyok Palaeo-suture, Ladakh Himalaya. 297: 142-144

Sharma KK. 1991. Tectonomagmatic and sedimentation history of ladakh collision zone: a synthesis. Physics and Chemistry of the Earth 17: 173-194

Sinha AK. 1992.Himalayan mountain building and tectonic processes involved in it. In: Sinha AK (ed) Himalayan Orogen and Geological Tectonic. Oxford and IBH Publ. Co., New Delhi/AA Balkema, Rotterdam, p1-18

Sinha AK and R Upadhyay. 1995. Himalaya: geological aspect. Palaeobotanist 44: 9-28

Srimal N. 1986. India-Asia collision: implication from the geology of the eastern Karakoram. Geology 14: 523-527

Thakur VC. 1992. Geology of Western Himalaya. Pergamon Press, Oxford. 366 p

Thakur VC and Misra DK. 1984. Tectonic framework of Indus and Shyok suture zones in eastern Ladakh, NW Himalaya. Tectonophysics 101: 207-220

Upadhyay, R. 2002. Stratigraphy and tectonics of Ladakh, eastren Karakoram, western Tibet, and western Kun Lun. Journal Geological Society of India 59: 447-467

Upadhyay R, AK Sinha, R Chandra and H Rai. 1999. Tectonic and magmatic evolution of the eastern Karakoram. Geodinamica Acta 12: 341-358 